\title{
PEMBERDAYAAN KELOMPOK TANI MELALUI PENINGKATAN NILAI GUNA RUMPUT LAUT Gracilaria sp. DI KECAMATAN WARA TIMUR KOTA PALOPO
}

\author{
Gita Srihidayati ${ }^{*}$, M. Rusli Baharuddin ${ }^{2}$, Eva Dwi Masni ${ }^{3}$ \\ ${ }^{1}$ Agroteknologi, Universitas Cokroaminoto Palopo, Indonesia \\ ${ }^{2,3}$ Pendidikan Matematika, Universitas Cokroaminoto Palopo, Indonesia \\ ${ }^{1}$ gita.sh988@gmail.com, ${ }^{2}$ mruslib@gmail.com
}

\begin{abstract}
ABSTRAK
Abstrak: Tujuan dari pelaksanaan kegiatan Program Kemitraan Masyarakat (PKM) kelompok petani rumput laut adalah untuk memberdayakan kelompok petani dalam meningkatkan nilai guna rumput laut Gracilaria $s p$. melalui penerapan metode pengeringan menggunakan bambu, mengembangkan diversifikasi produk olahan serta memanfaatkan limbah rumput laut sebagai pupuk organik cair (POC) pada tanaman. Target dan hasil yang diharapkan dari kegiatan ini adalah: 1) Peningkatan keterampilan petani dalam penanganan pasca panen rumput laut sehingga diperoleh rumput laut kering berkualitas, 2) Peningkatan pengetahuan dan keterampilan mitra dalam mengolah rumput laut menjadi produk olahan 3) Petani mampu membuat Pupuk Organik Cair (POC) berbahan dasar limbah rumput laut. Hasil pelaksanaan kegiatan PKM menunjukkan bahwa petani rumput laut yang berada di kecamatan Wara Timur Kota Palopo telah menerapkan teknik penanganan pasca panen yang tepat menggunakan alat bambu, mampu mengolah rumput laut menjadi produk olahan serta meminimalisir limbah rumput laut menjadi produk POC yang bermanfaat. Berdasarkan Penilaian Pelaksanaan Kegiatan pemberdayaan kelompok tani melalui peningkatan nilai guna rumput laut Gracilaria sp oleh mitra menunjukkan rerata skor 4,50 (kategori baik).
\end{abstract}

Kata Kunci: kelompok tani, rumput laut, Gracilaria sp., produk.

\begin{abstract}
The purpose of the implementation of the Community Partnership Program (CPP) group of seaweed farmers is to empower the group of farmers in increasing the value of the use of Gracillaria sp. seaweed through the application of drying methods using bamboo, developing diversified processed products and utilizing seaweed waste as a liquid organik fertilizer (LOF) on plants. The targets and expected outcomes of this activity are: 1) Improving the skills of farmers in handling post-harvest seaweed to obtain dry seaweed qualified, 2) Increasing the knowledge and skills of partners in processing seaweed into processed products 3) Farmers are able to make LOF from seaweed waste. The results of the implementation of CPP activities shows that seaweed farmers in Wara Timur sub-district of Palopo City have implemented appropriate postharvest handling techniques using bamboo tools, able to process seaweed into processed products and minimize seaweed waste into useful LOF products. Based on the Assessment of Implementation the empowerment activities of farmer groups through increasing the value of the use of Gracillaria sp. seaweed by partners showed a mean score of 4.50 (good category).
\end{abstract}

Keywords: the group of farmers, seaweed, Gracilaria sp., product. 


\section{A. LATAR BELAKANG}

Kota Palopo merupakan salah satu daerah yang memiliki potensi rumput laut yang sangat besar di Provinsi Sulawesi Selatan. Sebagian besar wilayah Kota Palopo didominasi oleh pesisir sehingga budidaya laut merupakan mata pencaharian terbesar di wilayah Palopo. Saat ini, budidaya rumput laut tidak hanya dilakukan di perairan pantai (laut) tetapi juga sudah mulai digalakkan pengembangannya di perairan payau (tambak) (Priono, 2016). Berdasarkan data Dinas Kelautan dan Perikanan (DKP) Kabupaten Luwu tahun 2015 menyatakan bahwa rata-rata produktivitas rumput laut dari tahun 2008-2014 mencapai sebesar 24,05 ton/hektar/tahun. Adapun produktivitas rumput laut di Kota Palopo dari tahun 2008-2014 mencapai 10,32 ton/hektar/tahun (Arifin \& Waluyo, 2018).

Salah satu contoh spesies yang bernilai ekonomis di Indonesia adalah Gracilaria sp. dari kelas Rhodophyceae. Rumput laut ini banyak digunakan sebagai bahan baku pembuatan agar-agar (Supriyantini, Santosa, \& Alamanda, 2018). Gracilaria sp. merupakan salah satu jenis rumput laut yang lebih banyak dibudidayakan oleh petani. Hal ini berbanding terbalik dengan rumput laut jenis Eucheuma cottoni. Rumput laut jenis gracilaria lebih mudah untuk dibudidayakan terutama di kandungan air payau dengan menggunakan bidang tambak sebagai tempat pembudidayaan sedangkan rumput laut jenis Eucheuma cottoni menggunakan bidang pesisir laut sebagai lokasi pembudidayaan sehingga lahannya terbatas (Risna, Munarka, \& Surullah, 2018).

Kawasan potensil budidaya rumput laut yang berada di kota palopo adalah di daerah Labombo yang meliputi tambak dan atau pantai. Berdasarkan hasil observasi dan wawancara tim pelaksana Program Kemitraan Masyarakat (PKM) dengan petani rumput laut labombo diperoleh informasi bahwa luas area produksi kedua mitra mencapai 11 hektar dengan total produksi mencapai 20 ton persekali panen yang dikelola secara mandiri. Petani rumput laut yang dijadikan mitra merupakan warga asli labombo tepatnya di Kecamatan Wara Timur, Kota Palopo.

Petani rumput laut di Kota Palopo membudidayakan hingga mengeringkan rumput laut dibawah sinar matahari selama 2 hari. Rumput laut kering atau dried seaweed akan dijual oleh petani pada para Peluncur, Pedagang Pengumpul hingga para Pedagang Besar dan para Eksportir. Secara umum, teknologi pascapanen rumput laut agarofit seperti Gracilaria sp. terdiri dari beberapa tahap, yakni proses pengangkutan, pemanenan, pencucian, pengeringan, dan pengemasan. Panen perdana rumput laut ini dilakukan setelah budidaya berlangsung selama empat bulan (Komarawidjaja, 2016). Terdapat berbagai variasi teknik pengeringan disebabkan oleh faktor sumberdaya manusia. Hal ini terkait dengan pemahaman pembudidaya rumput laut tentang kualitas rumput laut kering (Farman \& Teken, 2016). 
Petani rumput laut Gracilaria sp. memiliki produktivitas rumput laut melimpah sehingga sangat berpotensial untuk dikembangkan. Akan tetapi, penanganan pasca panen rumput laut belum optimal sehingga menyebabkan kualitas hasil panen menurun. Secara tidak langsung, hal ini mempengaruhi harga pasaran, dimana harga rumput laut kisaran Rp3000/kg. Perlu upaya penanganan pasca panen yang tepat sehingga dapat memperpanjang masa simpan hasil panen. Selain itu, dengan produktivitas yang tinggi dan harga jual yang cukup rendah, maka perlu dilakukan diversifikasi produk olahan berbasis rumput laut. Disamping diversifikasi produk, Gracilaria sp. mengandung ZPT yang berfungsi meningkatkan produksi buah, sayuran, bunga serta memperpanjang usia tanaman sehingga dapat digunakan sebagai pupuk organik (Komarawidjaja, 2016). Dengan kata lain, residu rumput laut yang tidak digunakan lagi dapat dijadikan sebagai pupuk organik cair sehingga secara tidak langsung dapat meminimalisir limbah rumput laut tersebut.

\section{B. METODE PELAKSANAAN}

Berdasarkan permasalahan yang dihadapi petani rumput laut di Kecamatan Wara Timur Kota Palopo yang berhasil diidentifikasi maka kegiatan yang dilaksanakan dalam menyelesaikan permasalahan mitra adalah:

1. Peningkatan pengetahuan dan keterampilan masyarakat tani dalam penanganan pasca panen rumput laut menggunakan metode pengeringan bambu.

2. Mitra dapat meningkatkan nilai guna rumput laut melalui olahan produk selai dan nugget.

3. Mitra mampu memanfaatkan limbah rumput laut menjadi pupuk organik cair.

Pelaksanaan kegiatan pelatihan penanganan pasca panen, pengolahan rumput laut dan pembuatan pupuk organik cair pada kelompok tani mengikuti kegiatan pelatihan selama 2 (dua) hari bertempat di kantor kelurahan Salekoe Kecamatan Wara Timur dan rumah warga petani pada tanggal 15-16 Mei 2018. Peserta yang mengikuti pelatihan sebanyak 15 orang.

Proses pengeringan rumput laut melalui pelatihan dari PKM adalah menerapkan konstruksi bambu/para-para'. Penjemuran rumput laut dengan menggunakan para-para dilakukan dengan cara menyiapkan dan membersihkan para-para dari kotoran, kemudian meletakkan rumput laut di atas parapara secara merata (Farman \& Teken, 2016), (Ilham \& Purwanti, 2016), (Lalopua, 2018). Pengeringan rumput laut berlangsung selama 2 hari.

Pembuatan selai rumput laut dengan cara rumput laut kering dicuci dengan air tawar sampai kering kemudian dilakukan perendaman selama 3 hari (Wonggo, 2010). Rumput laut lalu dipotong-potong $\pm 1-2 \mathrm{~cm}$, lalu 
masukkan ke dalam blender yang telah berisi air. Buah nanas ditambahkan air dan diblender hingga halus. Bubur nanas dan bubur rumput laut dicampur dan diaduk sampai merata. Bubur dimasak dengan api sedang sampai mendidih, lalu tambahkan gula pasir. Dimasak selama \pm 15-20 menit, tambahkan asam sitrat lalu aduk kembali selama 5- 10 menit hingga membentuk tekstur selai.

Prosedur pembuatan nugget ikan rumput laut meliputi ikan tenggiri dan rumput laut Gracilaria sp. sebagai bahan pengikat. Ikan yang digunakan kemudian disiangi dan diambil dagingnya. Daging ikan yang sudah bersih dihaluskan menggunakan blender (Masita \& Sukesi, 2015). Tambahkan tepung terigu, bumbu rempah yang telah dihaluskan, garam dan gula. Secara bertahap masukkan telur dan aduk hingga merata. Tuang adonan ke dalam loyang yang sudah diolesi minyak goreng atau margarin, kukus selama 15-20 menit. Setelah matang, diangkat, kemudian dicetak dengan ukuran $2 \mathrm{~cm} \times 2 \mathrm{~cm}$. Nugget dibalurkan ke dalam kocokan telur, baluri dengan tepung panir. Nugget yang telah jadi dikemas dan disimpan dalam freezer.

Pada program ini, dilakukan penyuluhan dan pelatihan mengenai pemanfaatan limbah rumput laut Gracilaria sp. Limbah rumput laut dicuci bersih menggunakan air untuk menghilangkan lumpur, pasir, serta kotoran yang menempel pada talus. Rumput laut dicacah secara manual dengan ukuran $\pm 5 \mathrm{~cm}$, kemudian masing-masing rumput laut dimasukkan kedalam wadah komposter yang terbuat dari bahan plastik. Untuk mempercepat proses penguraian digunakan starter bakteri komersial EM4. Bakteri komersial EM4 diencerkan dalam air dan disemprotkan ke permukaan limbah rumput laut $( \pm 200 \mathrm{ml}$ larutan untuk $10 \mathrm{~kg}$ rumput laut) dan juga limbah rumah tangga yang tediri dari campuran nasi dan sayuran. Limbah digunakan sebagai media nutrisi untuk penguraian dan meningkatkankandungan hara pupuk yang dihasilkan.Jumlah keseluruhan bahan-bahan yang dimasukkan $\pm 3 / 4$ volume wadah komposter (Susianingsih \& Nurbaya, 2011), (Sedayu, Erawan, \& Assadad, 2014).

\section{HASIL DAN PEMBAHASAN}

\section{Hasil Pelaksanaan Program Kemitraan Masyarakat}

Program utama dari kegiatan PKM adalah sosialisasi penanganan pasca panen rumput laut, pelatihan diversifikasi produk olahan rumput laut serta pemanfaatan limbah menjadi pupuk organik cair. Rumput laut dapat diolah menjadi produk pangan yang kaya gizi. Teknik pengolahan yang diberikan ke masyarakat menggunakan metode sederhana serta peralatan dan bahan yang digunakan mudah dijangkau. Sebelum dilakukan pelatihan pengolahan rumput laut, terlebih dahulu diberikan penyuluhan mengenai preparasi rumput laut yang digunakan. Sebelum diolah, rumput laut direndam selama 3 hari dengan perasan jeruk nipis dan dibilas hingga bersih. Tujuan dari perendaman rumput laut 
Gracilaria sp. adalah untuk mempermudah proses penghancuran rumput laut menjadi bubur. Setelah itu, bubur rumput laut ini dapat dijadikan sebagai bahan dasar pembuatan selai dan nugget rumput laut. Selain itu, limbah rumput laut yang tidak digunakan dapat dimanfaatkan lagi oleh petani sebagai bahan dasar dalam pembuatan pupuk cair.

Melalui kegiatan ini, tim pelaksana PKM memberikan pelatihan secara sederhana sehingga para peserta mudah memahami. Meskipun presentasi yang dilakukan secara sederhana, akan tetapi penyuluhan dan pelatihan yang dilakukan dengan penerapan atau contoh yang menarik mampu memicu semangat dan antusias peserta dalam menerapkan hasil pelatihan tersebut.

Melalui penjelasan pelatihan penanganan pasca panen rumput laut, maka petani akan memperoleh informasi tentang bagaimana penanganan hasil panen rumput laut yang tepat hingga dapat mempertahankan kualitas serta memperpanjang masa simpan rumput laut. Untuk mewujudkan hal tersebut maka di hadirkan beberapa pakar seperti ahli budidaya rumput laut, ahli pengelolaan sumberdaya alam dan lingkungan dan ahli teknologi pertanian (Gambar 1).

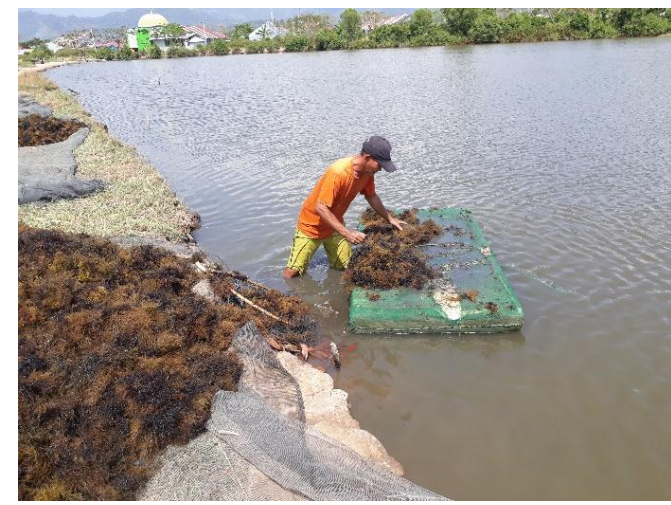

Gambar 1. Penanganan Pasca Panen Rumput Laut

Dari hasil penyuluhan yang telah dilakukan, petani rumput laut mampu memahami cara meningkatkan kualitas rumput laut melalui teknik penanganan pasca panen yang tepat. Penerapan media pengeringan bambu sebagai alternatif proses pengeringan rumput laut akan sangat membantu petani jika cuaca menjadi mendung atau hujan, mengingat curah hujan di Kota Palopo cukup tinggi. Sehingga hal tersebut akan mengurangi terjadinya pembusukan selama proses pengeringan. Selain itu, Rumput laut kering yang dihasilkan petani menjadi lebih bersih karena proses pengeringan yang dilakukan terhindar dari benda asing yang dapat mengotori rumput laut seperti debu, tanah, pasir, batu kecil dan benda asing yang lain. Hasil rumput laut basah yang diperoleh petani pada lahan 7 ha mencapai 18 ton dengan berat kering sebesar 1,8 ton. 
Selain pelatihan pengeringan rumput laut, telah dilaksanakan kegiatan diversifikasi produk olahan rumput laut melalui pemberian pelatihan kepada ibu- ibu PKK dan ibu rumah tangga dengan bermata pencaharian sebagai petani rumput laut. Hasil dari pelatihan ini dapat meningkatkan pengetahuan dan keterampilan ibu-ibu PKK dan ibu rumah tangga dalam mengolah rumput laut menjadi produk yang berkualitas dan bermanfaat (Gambar 2 dan Gambar 3).

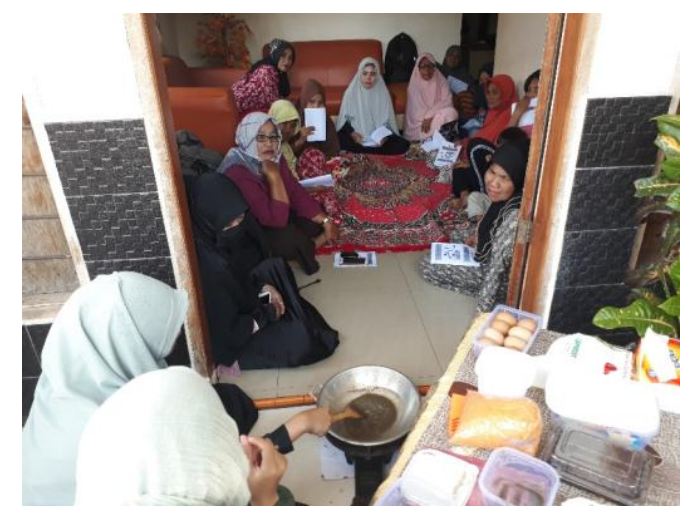

Gambar 2. Pelatihan Pengolahan Rumput Laut menjadi Selai Gracilaria sp.

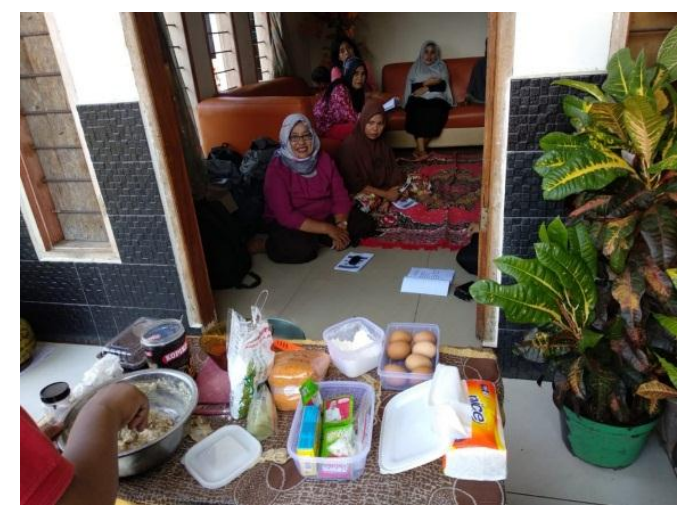

Gambar 3. Pelatihan Pengolahan Rumput Laut menjadi Nugget Gracilaria sp.

Selama pendampingan, tingkat pengetahuan dan keterampilan ibu rumah tangga mengalami peningkatan. Selaku sebagai mitra PKM, mereka sangat antusias dalam memanfaatkan rumput laut menjadi bahan dasar olahan dalam membuat makanan, seperti selai dan nugget (Gambar 4a dan 4b).

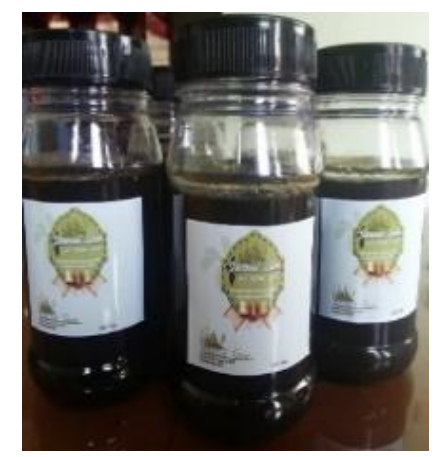

(a)

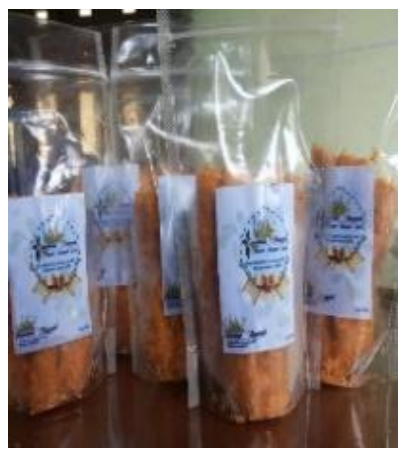

(b)

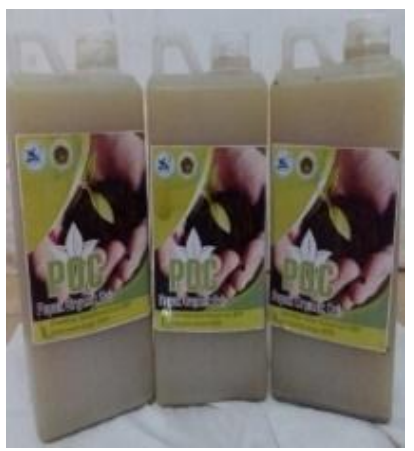

(c)

Gambar 4. Produk (a) selai; (b) nugget; (c) Pupuk Organik Cair berbahan dasar Rumput Laut Gracilaria sp. 
Berdasarkan dari hasil observasi di lapangan, mitra mengemukakan bahwa produk selai dapat mereka manfaatkan sebagai bahan isian kue kering pada saat hari raya dan nugget menjadi camilan dalam penyajian menu keluarga. Keberlanjutan dari hasil kegiatan ini dapat mereka manfaatkan sebagai pendapatan tambahan dengan cara memasarkan produk yang telah dibuat.

Salah satu program dari PKM adalah menghasilkan luaran produk yang bernilai guna, bukan hanya dari segi olahan pangan tetapi dari aspek lingkungan. Limbah rumput laut merupakan residu dari hasil panen rumput laut yang tidak digunakan oleh masyarakat tani. Kurangnya pemahaman petani mengenai pembuatan pupuk organik cair membuat limbah rumput laut semakin terabaikan untuk dimanfaatkan. Kandungan yang terdapat didalam rumput laut dapat digunakan sebagai pupuk yang bermanfaat bagi tanaman.

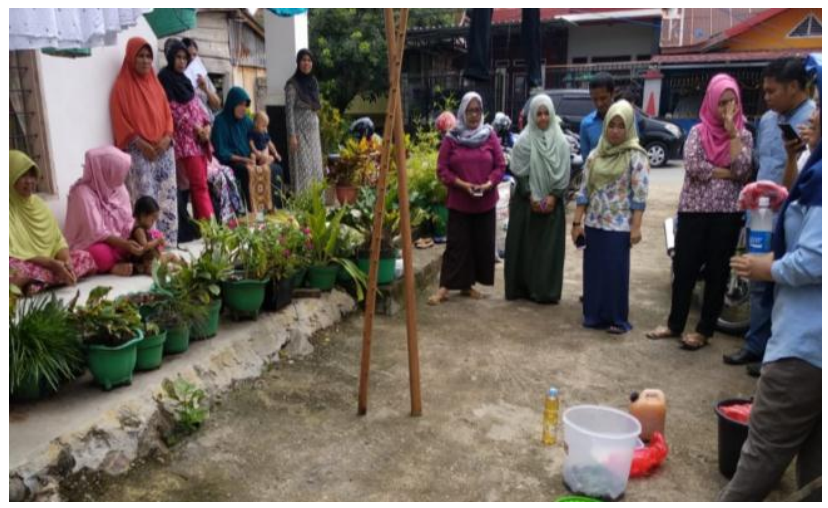

Gambar 5. Demonstrasi pemanfaatan limbah rumput laut sebagai bahan dasar POC

Pemanfaatan limbah rumput laut dan limbah rumah tangga dijadikan sebagai pupuk organik cair. Limbah Rumah yang didemonstrasikan adalah nasi basi, buah-buahan busuk, sayuran dan cucian air beras (Gambar 5). Ibu PKK dan ibu rumah tangga di bekali pelatihan pembuatan POC (Pupuk Organik Cair) dan diberikan pendampingan cara pemakaian pupuk hasil fermentasi. Penerapan pupuk organik cair pada tanaman hias merupakan salah satu langkah meminimalisir limbah rumput laut serta petani dapat mengelola limbah menjadi produk yang lebih bermanfaat (Gambar 4c).

\section{Monitoring dan Evaluasi Program}

Selama proses kegaitan PKM tim pelaksana melakukan monitoring selama 2 kali seminggu dan evaluasi program dilakukan secara bertahap dengan memperhatikan setiap aspek tahapan kegiatan yang telah dilakukan sebagai indikator keberhasilan program secara internal dan eksternal.

Tabel 1. Hasil Pencapaian Mitra Selama Mengikuti PKM

\begin{tabular}{|l|l|c|}
\hline No & Indikator Pencapaian & Skor \\
\hline
\end{tabular}




\begin{tabular}{|c|l|c|}
\hline 1 & $\begin{array}{l}\text { Mitra mampu mengetahui potensi pengembangan } \\
\text { komoditi Rumput Laut Gracilaria sp. }\end{array}$ & 4,33 \\
\hline 2 & $\begin{array}{l}\text { Keterampilam mitra meningkat setelah } \\
\text { pelatihan/pendampingan }\end{array}$ & 4,40 \\
\hline 3 & Mitra mengetahui nilai guna produk yang dihasilkan & 4,40 \\
\hline 4 & $\begin{array}{l}\text { Mitra mampu membuat/ menerapkan produk secara } \\
\text { mandiri }\end{array}$ & 4,47 \\
\hline 5 & Hasil produk yang diperoleh sangat bermanfaat & 4,67 \\
\hline 6 & Mitra sangat antusias mengikuti program selanjutnya & 4,73 \\
\hline \multicolumn{2}{|l}{ Rerata Skor } & $\mathbf{4 , 5 0}$ \\
\hline
\end{tabular}

Evaluasi pencapaian yang diperoleh Mitra selama pendampingan dari berbagai aspek ditunjukkan pada Tabel 1 dengan rerata skor 4,50 (kategori tercapai). Sebelum program PKM dilaksanakan, hasil survey menunjukkan cara penanganan pasca panen rumput laut oleh masyarakat tani belum memperhatikan aspek kebersihan dan kualitas dari rumput laut yang dijual. Selain itu, petani juga belum mengetahui potensi besar komoditi rumput laut untuk dikembangkan dalam bentuk produk olahan. Kebanyakan mereka hanya menjualnya secara langsung dalam bentuk rumput laut kering. Akan tetapi, setelah mitra mengikuti PKM, mereka menyadari peran penanganan pasca panen rumput laut yang optimal mampu meningkatkan dan mempertahankan kualitas rumput laut. Komoditi ini dapat dikembangkan dalam bentuk produk lain yang lebih bermanfaat.

\section{SIMPULAN DAN SARAN}

Berdasarkan hasil pelaksanaan PKM, maka dapat disimpulkan bahwa petani rumput laut mampu menerapkan metode pengeringan menggunakan bambu, pengetahuan dan keterampilan petani rumput laut meningkat dalam mengolah rumput laut menjadi produk olahan yang berkualitas dan mampu membuat pupuk organik cair (POC) pada tanaman dengan memanfaatkan serta meminimalisir limbah rumput laut. Disamping itu, berdasarkan penilaian pelaksanaan kegiatan pemberdayaan kelompok tani melalui peningkatan nilai guna rumput laut Gracilaria sp. oleh mitra menunjukkan rerata skor 4,50 (kategori baik).

Program Kemitraan Masyarakat pada mitra petani rumput laut untuk selanjutnya perlu diterapkan manajemen usaha sehingga petani memiliki pengetahuan dan keterampilan terutama dalam pemasaran produk. Selain itu, diharapkan kelompok tani rumput laut dapat melanjutkan program PKM yang telah dilaksanakan sehingga petani mampu meningkatkan nilai guna rumput laut.

\section{UCAPAN TERIMA KASIH}

Ucapan terima kasih kami sampaikan kepada Ketua Lembaga PPM Universitas Cokroaminoto Palopo dan Pemerintah Kecamatan Wara Timur 
Kota Palopo yang telah membantu dan memfasilitasi kegiatan serta kepada pihak-pihak yang membantu pelaksanaan program ini.

\section{DAFTAR RUJUKAN}

Arifin, T., \& Waluyo, W. (2018). Analisis Daya Dukung Ekologi Untuk Pengembangan Budidaya Rumput Laut Di Bagian Utara Teluk Bone. Tataloka, 20(1), 12. https://doi.org/10.14710/tataloka.20.1.12-22

Farman, A., \& Teken, Y. (2016). Konstruksi Wadah Vertikultur Untuk Budidaya Rumput Laut Kotoni. Buletin Teknik Litkayasa Akuakultur, 14(2), 77. https://doi.org/10.15578/blta.14.2.2016.77-82

Ilham, I., \& Purwanti, D. A. (2016). Konstruksi wadah budidaya rumput laut sargassum sp. Dengan metode lepas dasar. Buletin Teknik Litkayasa Akuakultur, 14(2), 73. https://doi.org/10.15578/blta.14.2.2016.73-75

Komarawidjaja, W. (2016). Kajian Pemanfaatan Limbah Padat Industri Pengolahan Rumput Laut Sebagai Media Kultur Mikroalga Chlorella sp. Jurnal Teknologi Lingkungan, 12(3), 241. https://doi.org/10.29122/jtl.v12i3.1232

Lalopua, V. M. (2018). Hypnea saidana Menggunakan Metode Pembuatan Berbeda Dengan Penjemuran Matahari. Fakultas Perikanan Dan Ilmu Kelautan Universitas Patimura Ambon, 14(01), 28-36.

Masita, H. I., \& Sukesi. (2015). Pengaruh Penambahan Rumput Laut terhadap Kekerasan Nugget Ikan. Jurnal Sains Dan Seni, 4(1), 29-31. https://doi.org/2337-3520

Priono, B. (2016). Budidaya Rumput Laut Dalam Upaya Peningkatan Industrialisasi Perikanan. Media Akuakultur, 8(1), 1. https://doi.org/10.15578/ma.8.1.2013.1-8

Risna, R., Munarka, H., \& Surullah, M. (2018). Pengaruh Modal Dan Luas Lahan Terhadap Produksi Rumput Laut (Gracillaria Sp) Di Desa Lampuara Kecamatan Ponrang Selatan Kabupaten Luwu. Jurnal Ekonomi Pembangunan STIE Muhammadiyah Palopo, 4(1). https://doi.org/10.35906/jep01.v4i1.291

Sedayu, B. B., Erawan, I. M. S., \& Assadad, L. (2014). Pupuk Cair dari Rumput Laut Eucheuma cottonii, Sargassum sp. dan Gracilaria sp. Menggunakan Proses Pengomposan. Jurnal Pascapanen Dan Bioteknologi Kelautan Dan Perikanan, 9(1), 61. https://doi.org/10.15578/jpbkp.v9i1.100

Supriyantini, E., Santosa, G. W., \& Alamanda, L. N. (2018). Pertumbuhan Rumput Laut Gracilaria sp. pada Media yang Mengandung Tembaga $(\mathrm{Cu})$ dengan Konsentrasi yang $\begin{array}{lllll}\text { Berbeda. } \quad \text { Buletin } & \text { Oseanografi }\end{array}$ https://doi.org/10.14710/buloma.v7i1.19038

Susianingsih, E., \& Nurbaya, N. (2011). Jenis Dan Dosis Aktivator Pada Pembuatan Kompos Berbahan Baku Makroalga. Media Akuakultur, 6(1), 25. https://doi.org/10.15578/ma.6.1.2011.25-31

Wonggo, D. (2010). Penerimaan Konsumen Terhadap Selai Rumput Laut (Kappaphycus alvarezii). Jurnal Perikanan Dan Kelautan Tropis, 6(1), 51. https://doi.org/10.35800/jpkt.6.1.2010.118 